\title{
Regulation of Calcitonin Gene Transcription by Vitamin D Metabolites In Vivo in the Rat
}

Tally Naveh-Many and Justin Silver

Nephrology Services, Hadassah University Hospital, Jerusalem, i1-91120 Israel

\section{Abstract}

Calcitonin is secreted by the $\mathbf{C}$ cells of the thyroid in response to a raised serum calcium, and acts on bone to lower serum calcium. The $\mathbf{C}$ cells have specific receptors for the dihydroxymetabolite of vitamin $\mathrm{D}_{3}, 1,25(\mathrm{OH})_{2} \mathrm{D}_{3}$. Moreover, calcitonin stimulates the synthesis of $1,25(\mathrm{OH})_{2} \mathrm{D}_{3}$ in the kidney. Parathyroid hormone (PTH), the third calciotrophic hormone, is also trophic to the renal synthesis of $1,25(\mathrm{OH})_{2} \mathrm{D}_{3}$, and in turn $1,25(\mathrm{OH})_{2} \mathrm{D}_{3}$ inhibits PTH gene transcription and synthesis. We report here the marked inhibition of calcitonin gene transcription by the injection of physiologically relevant doses of $1,25(\mathrm{OH})_{2} \mathrm{D}_{3}$ to normal rats that did not raise serum calcium. Calcitonin mRNA levels after 100 pmol $1,25(\mathrm{OH})_{2} \mathrm{D}_{3}$ decreased to $6 \%$ of basal at $6 \mathrm{~h}$ and $4 \%$ at $48 \mathrm{~h}$, and a dose response showed a marked effect even after $12.5 \mathrm{pmol}$ $1,25(\mathrm{OH})_{2} \mathrm{D}_{3}$, with no appreciably greater effect with larger doses (up to 200 pmol). Control genes, actin, thyroglobulin (thyroid follicular cells), somatostatin (thyroid C-cells) were not affected by $1,25(\mathrm{OH})_{2} \mathrm{D}_{3}$. Gel blots showed that $1,25(\mathrm{OH})_{2} \mathrm{D}_{3}$ decreased calcitonin mRNA levels without any change in its size. In vitro nuclear transcription showed that $1,25(\mathrm{OH})_{2} \mathrm{D}_{3}$-treated $(100 \mathrm{pmol})$ rats' calcitonin transcription was $10 \%$ of control, while thyroglobulin and actin were $100 \%$. We propose that calcium is the major regulator of PTH and calcitonin secretion, while $1,25(\mathrm{OH})_{2} \mathrm{D}_{3}$ is an important regulator of PTH and calcitonin gene transcription. We believe this to be the first demonstration of an effect of $1,25(\mathrm{OH})_{2} \mathrm{D}_{3}$ on the $C$ cells thereby establishing a new target organ and site of action of vitamin $\mathrm{D}$. Calcitonin is trophic to $1,25(\mathrm{OH})_{2} \mathrm{D}_{3}$ synthesis, which in turn inhibits calcitonin synthesis, which are the components of a new endocrinological feedback loop.

\section{Introduction}

Calcitonin, parathyroid hormone (PTH) and 1,25-dihydroxyvitamin $\mathrm{D}_{3}\left(1,25(\mathrm{OH})_{2} \mathrm{D}_{3}\right)^{1}$ are the three major hormones that determine calcium homeostasis. A low calcium stimulates PTH secretion and a high calcium calcitonin secretion, while

\footnotetext{
Address reprint requests to Dr. Silver, Nephrology Services, Hadassah University Hospital, P.O.B. 12000, Jerusalem, Israel 91120.

Received for publication 5 January 1987 and in revised form 8 September 1987.
}

1. Abbreviations used in this paper: CGRP, calcitonin gene-related peptide; $1,25(\mathrm{OH})_{2} \mathrm{D}_{3}, 1,25$-dihydroxyvitamin $\mathrm{D}_{3}$.

J. Clin. Invest.

(C) The American Society for Clinical Investigation, Inc. $0021-9738 / 88 / 01 / 0270 / 04 \$ 2.00$

Volume 81, January 1988, 270-273 both PTH and calcitonin are trophic to the synthesis of $1,25(\mathrm{OH})_{2} \mathrm{D}_{3}$ in the kidney. The major regulator of PTH gene transcription both in vitro and in vivo is $1,25(\mathrm{OH})_{2} \mathrm{D}_{3}(1,2)$. Feedback loops are a characteristic feature of hormone relationships and since calcitonin increases the synthesis of $1,25(\mathrm{OH})_{2} \mathrm{D}_{3}(3-5)$ by selectively stimulating the $25(\mathrm{OH}) \mathrm{D}_{3}$ 1-hydroxylase enzyme in the proximal straight tubule of rat kidney nephron (6), the question arose whether $1,25(\mathrm{OH})_{2} \mathrm{D}_{3}$ affected calcitonin production. $1,25(\mathrm{OH})_{2} \mathrm{D}_{3}$ acts on target cells like classical steroid hormones by binding to stereospecific high affinity receptors that then translocate to the nucleus to affect gene expression. In mammals, calcitonin is produced principally in the parafollicular or $\mathrm{C}$ cells of the thyroid gland that comprise less than $10 \%$ of total thyroid cells in rats (7) and $0.1 \%$ in adult humans (8), therefore it would not be possible to detect the presence of $1,25(\mathrm{OH})_{2} \mathrm{D}_{3}$ receptors in whole thyroid cytosols. Medullary thyroid carcinomas are $\mathrm{C}$ cell carcinomas, which secrete calcitonin, and Freake and MacIntyre demonstrated the presence of the $1,25(\mathrm{OH})_{2} \mathrm{D}_{3}$-binding protein in the cytosol prepared from human medullary thyroid carcinomas (9). The protein was not present in normal thyroid cytosols, probably reflecting the low proportion of $\mathrm{C}$ cells. The presence of $1,25(\mathrm{OH})_{2} \mathrm{D}_{3}$-binding protein in $\mathrm{C}$ cells suggests that they might be a target site for $1,25(\mathrm{OH})_{2} \mathrm{D}_{3}$. The effect of injected $1,25(\mathrm{OH})_{2} \mathrm{D}_{3}$ on serum calcitonin has produced conflicting results with small doses given to humans having no effect on calcitonin up to $2 \mathrm{~h}(10)$, while rats given large doses (1.2 $\mathrm{nmol}$ ) had an increase in calcitonin at least partially due to hypercalcemia (11), or a decrease in the calcitonin response to calcium load together with a decrease in intrathyroidal calcitonin (12). After a large dose of $1,25(\mathrm{OH})_{2} \mathrm{D}_{3}(500 \mathrm{pmol} / 200 \mathrm{~g}$ rat) Segond et al. (13) found no change in intrathyroidal calcitonin with a transient increase in calcitonin mRNA (1-2 h) that decreased at 4-16 h. We had shown in vivo in the rat that $1,25(\mathrm{OH})_{2} \mathrm{D}_{3}$ was a potent inhibitor of PTH gene transcription, reducing PTH mRNA levels by $75 \%$ and PTH nuclear transcription by $90 \% 24 \mathrm{~h}$ after a single injection of a small dose of $1,25(\mathrm{OH})_{2} \mathrm{D}_{3}(1)$. For those experiments the thyroid and parathyroid were usually excised together, and RNA was extracted from both tissues for dot blot analysis of PTH mRNA. We have now rehybridized the same filters to study whether $1,25(\mathrm{OH})_{2} \mathrm{D}_{3}$ regulates calcitonin $\mathrm{mRNA}$ levels, and calcitonin gene transcription. The following control genes were used: actin for total thyroparathyroid tissue, thyroglobulin for thyroid follicular cells and somatostatin that like calcitonin, is localized to the C cells of the thyroid (14).

\section{Methods}

Animals. As previously described (1) normal male rats of the Hebrew University strain had been injected intraperitoneally with vitamin D 
metabolites dissolved in propylene glycol $(100 \mu \mathrm{l})$ and at timed intervals the parathyroid-thyroid glands were excised in liquid nitrogen and stored at $-20^{\circ} \mathrm{C}$ until extraction.

$R N A$ extraction and hybridization. Total parathyroid-thyroid tissue RNA was prepared by extraction with guanidine thiocyanate and guanidine hydrochloride (15) and then spotted on nitrocellulose filters with and without further dilution for dot blot analysis. The filters were then hybridized with nick translated cDNA probes $\left(2-5 \times 10^{8} \mathrm{cpm} / \mu \mathrm{g}\right)$, autoradiographed and the films scanned with a densitometer. The filters were extensively washed and then rehybridized with further probes. The calcitonin probe is an $\sim 900 \mathrm{bp}$ cDNA (16) fragment. The thyroglobulin probe is a 640 -bp cDNA fragment that represents part of the structural gene (17). The somatostatin probe is a synthetic polynucleotide of $46 \mathrm{bp}$, and represents part of the somatostatin cDNA (18). The data for PTH mRNA and actin mRNA has been published previously (1). For gel blot analysis, total RNA from thyroid-parathyroid tissue was extracted, denatured, and size fractionated by electrophoresis on $1.5 \%$ agarose gels containing formaldehyde and transferred to nitrocellulose filters by diffusion blotting (1). RNA size was determined from the migration of ribosomal RNA markers. The same amounts of RNA were run from control and $1,25(\mathrm{OH})_{2} \mathrm{D}_{3}$-treated rats, as quantitated by ethidium bromide staining and by spectrophotometry $\left(\mathrm{OD}_{260} / \mathrm{OD}_{280}=2\right)$. Filters were hybridized sequentially with ${ }^{32} \mathrm{P}$ nick translated cDNAs for preproPTH (1), calcitonin, and actin. Both in the dot blots and Northern blots the sequence of hybridization with different probes was random.

Nuclear transcription and RNA isolation. In vitro nuclear transcription run-offs were performed using $5 \times 10^{6}$ nuclei $/ \mathrm{ml}, 200 \mu \mathrm{Ci}$ of [ $\left.\alpha{ }^{32} \mathrm{P}\right]$ UTP $(400 \mathrm{Ci} / \mathrm{mmol})$, and an incubation for $10 \mathrm{~min}$ at $26^{\circ} \mathrm{C}$ as previously described (1). The transcribed RNA was hybridized to filters prepared by spotting $5 \mu \mathrm{g}$ of linearized denatured plasmid DNAs on nitrocellulose. Each dot of immobilized DNA was punched out from the filter strips and the radioactivity determined by liquid scintillation counting.

\section{Results}

$1,25(\mathrm{OH})_{2} \mathrm{D}_{3}(100 \mathrm{pmol})$ led to a marked reduction in preproPTH mRNA reaching $50 \%$ at $6 \mathrm{~h}$ and $4 \%$ at $48 \mathrm{~h}$ (1). Calcitonin mRNA levels show an even more dramatic change in response to $1,25(\mathrm{OH})_{2} \mathrm{D}_{3}$ than PTH mRNA. At $6 \mathrm{~h}$ after $1,25(\mathrm{OH})_{2} \mathrm{D}_{3}$ injection calcitonin mRNA levels were $6 \%$ of basal, and $2 \%$ at $48 \mathrm{~h}$ (Fig. 1). There was no change in these same RNA tissue extracts for somatostatin mRNA, thyroglobulin mRNA, and actin mRNA, showing that there was no generalized decrease in mRNA levels. The constant amount of actin mRNA indicated that the RNA extraction did not vary. The response is concentration dependent but with a major effect on both PTH and calcitonin mRNAs at $12.5 \mathrm{pmol}$ $1,25(\mathrm{OH})_{2} \mathrm{D}_{3}$ and little change from 50 to 200 pmol (Fig. 2). The response is also metabolite specific with decreasing order of potency: $1,25(\mathrm{OH})_{2} \mathrm{D}_{3}, 24,25(\mathrm{OH})_{2} \mathrm{D}_{3}, 25(\mathrm{OH})_{2} \mathrm{D}_{3}$ vitamin $\mathrm{D}_{3}$ (results not shown). An agarose gel of extracted RNA (Northern blot) showed that from a $1,25(\mathrm{OH})_{2} \mathrm{D}_{3}$-treated rat the calcitonin mRNA was markedly reduced as compared with a control rat, while there was no effect on actin mRNA (Fig. 3). Both PTH mRNA (833 bp) (1) and calcitonin mRNA (900 bp) ran as single bands showing that the effect of $1,25(\mathrm{OH})_{2} \mathrm{D}_{3}$ was not on mRNA processing but on mRNA synthesis or degradation. In vitro nuclear transcription run-off experiments, in which transcription that had been initiated in vivo is elongated and completed in vitro, demonstrated that $1,25(\mathrm{OH})_{2} \mathrm{D}_{3}$ decreased calcitonin transcription to $10 \%$ of control, while thyroglobulin transcription was $100 \%$ of control (Fig. 4). We had previously shown that $1,25(\mathrm{OH})_{2} \mathrm{D}_{3}$ had no

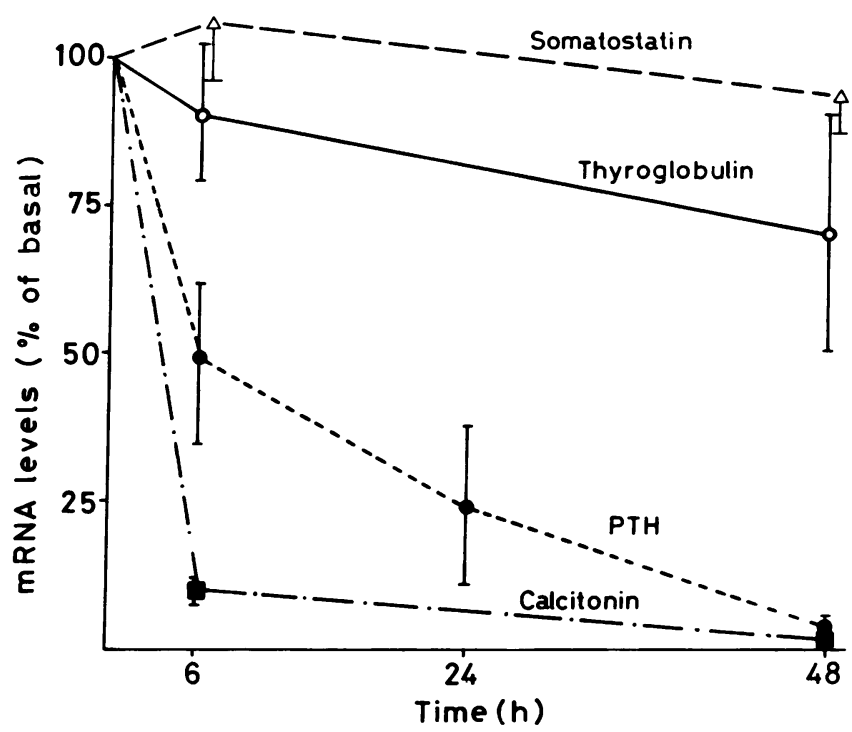

Figure 1. Time course of the effect of $1,25(\mathrm{OH})_{2} \mathrm{D}_{3}(100 \mathrm{pmol})$ on mRNA levels for thyroglobulin (o), preproparathyroid hormone (๑), calcitonin ( () and somatostatin $(\Delta)$ of rat parathyroid-thyroid glands. Levels of mRNA for parathyroid hormone, calcitonin, thyroglobulin, somatostatin, and $\beta$-actin (not shown) were determined sequentially by hybridization with nick translated rat cDNA probes. The data for PTH mRNA has been published previously (1). The results at each point are the mean $\pm \mathrm{SE}$ for four rats and expressed as a percentage of basal.

effect on actin transcription but decreased PTH transcription to $10 \%$ of control (1). This indicates that a major effect of $1,25(\mathrm{OH})_{2} \mathrm{D}_{3}$ is on calcitonin mRNA synthesis. The serum calciums were not elevated by the small single doses of $1,25(\mathrm{OH})_{2} \mathrm{D}_{3}$ injected to the rats.

\section{Discussion}

The action of $1,25(\mathrm{OH})_{2} \mathrm{D}_{3}$ is classically mediated by its action on the genome of target cells by either stimulating (e.g., calcium binding protein [19], osteocalcin [20], prolactin [21]), or inhibiting transcription (e.g., collagen [22], PTH [1], C-myc oncogene [23]), and hence the synthesis of the respective proteins. The $\mathrm{C}$ cells of the thyroid that secrete calcitonin have receptors for $1,25(\mathrm{OH})_{2} \mathrm{D}_{3}(9)$, and we have now demonstrated that $1,25(\mathrm{OH})_{2} \mathrm{D}_{3}$ regulates calcitonin gene transcription, thus

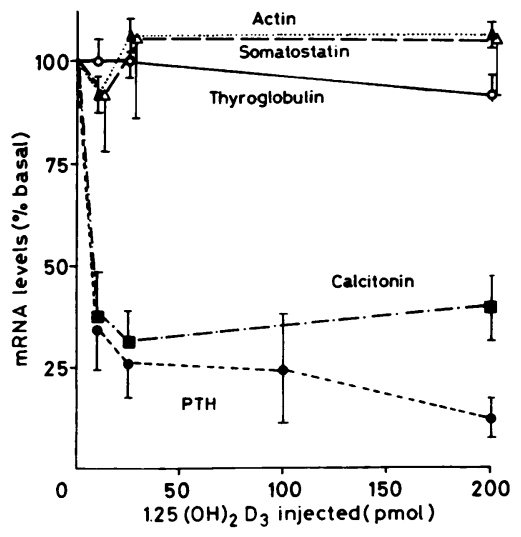

Figure 2. $1,25(\mathrm{OH})_{2} \mathrm{D}_{3}$ dose-response effect at $24 \mathrm{~h}$ after injection to rats of parathyroid-thyroid tissue levels of mRNA for $\beta$-actin ( $\Delta$ ), thyroglobulin (O), calcitonin (घ), somatostatin $(\Delta)$, and preproparathyroid hormone (๑). The results represent mean \pm SEM for four rats. 


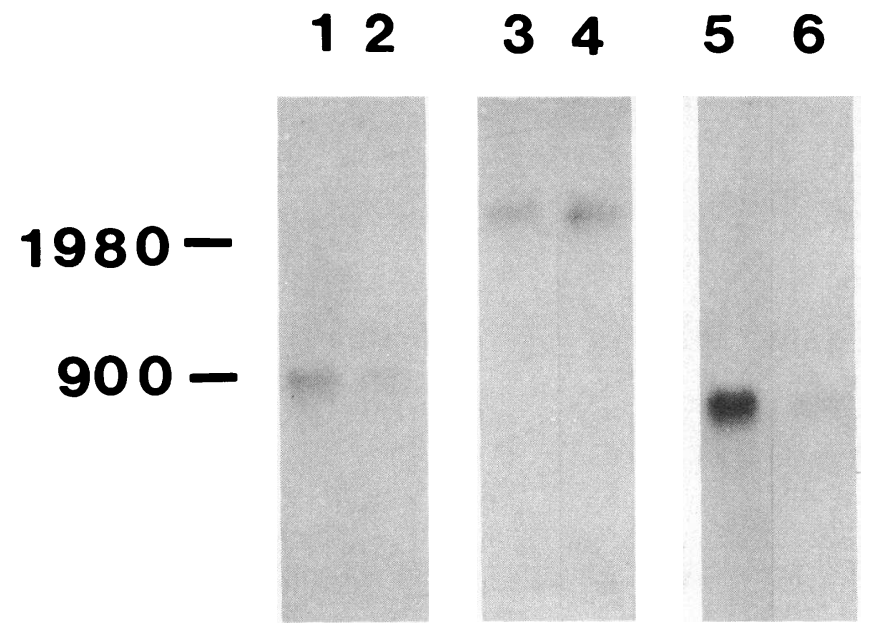

Figure 3. Gel blot analysis of total RNA from parathyroid thyroid tissue. Filters were hybridized sequentially with ${ }^{32} \mathrm{P}$ nick translated cDNAs for preproPTH (1), calcitonin and actin. Lanes: 1 , calcitonin mRNA from parathyroid-thyroid tissue of 1 control rat; 2 , calcitonin mRNA from parathyroid-thyroid tissue of 1 rat $24 \mathrm{~h}$ after 100 pmol $1,25(\mathrm{OH})_{2} \mathrm{D}_{3}$ i.p. 3 , actin mRNA from the control rat parathyroidthyroid tissue (as in lane 1 ); 4, actin mRNA from the $1,25(\mathrm{OH})_{2} \mathrm{D}_{3}$ treated rat (as in lane 2); 5, PTH mRNA from the control rat; 6 , PTH mRNA from the $1,25(\mathrm{OH})_{2} \mathrm{D}_{3}$-treated rat.

providing evidence that the $\mathrm{C}$ cell of the thyroid is a target organ for vitamin D. Somatostatin is also present only in thyroid C cells and not in thyroid follicular cells (14). Somatostatin mRNA was not affected by $1,25(\mathrm{OH})_{2} \mathrm{D}_{3}$, demonstrating that the effect of $1,25(\mathrm{OH})_{2} \mathrm{D}_{3}$ is specific for the calcitonin gene. The thyroid follicular cells have no receptors for $1,25(\mathrm{OH})_{2} \mathrm{D}_{3}(9)$ and there was no change in thyroglobulin mRNA levels in response to $1,25(\mathrm{OH})_{2} \mathrm{D}_{3}$, confirming the specificity of the effect on the calcitonin gene. Calcitonin gene related peptide (CGRP) is derived from the same gene as calcitonin (24), and therefore also might be regulated by $1,25(\mathrm{OH})_{2} \mathrm{D}_{3}$ but its level of expression in the $\mathrm{C}$ cell is low, and hence of limited significance. Calcitonin stimulates $1,25(\mathrm{OH})_{2} \mathrm{D}_{3}$ synthesis (3-6) and our findings that

CONTROL

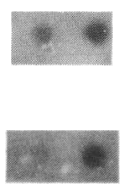

$1,25(\mathrm{OH}){ }_{2} \mathrm{D}_{3}$

(100 pmo1)

Figure 4. Nuclear transcription run-offs for calcitonin and thyroglobulin of control and $1,25(\mathrm{OH})_{2} \mathrm{D}_{3}$-treated rats. Nuclei were isolated from the parathyroid-thyroid tissue of 18 control rats and 18 rats treated with $1,25(\mathrm{OH})_{2} \mathrm{D}_{3} 100$ pmol i.p. $24 \mathrm{~h}$ earlier. Newly synthesized $m R N A$ sequences were quantitated by hybridization to immobilized cDNA for calcitonin, thyroglobulin and pBR 322 plasmid as a nonspecific control as described previously (1). There was no hybridization with pBR 322 plasmid. The results expressed as parts per million of total input ${ }^{32} \mathrm{P}$ RNA $\left(\sim 9.8 \times 10^{6} \mathrm{cpm}\right)$ minus radioactivity bound to the pBR 322 dot were for control and $1,25(\mathrm{OH})_{2} \mathrm{D}_{3^{-}}$ treated rats, respectively: calcitonin 20.0:2.3 and thyroglobulin 70.6:73.3.

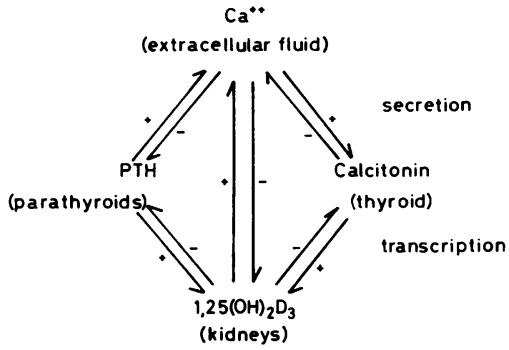

Figure 5. Proposed interrelationship between serum calcium concentration, parathyroid hormone, $1,25(\mathrm{OH})_{2} \mathrm{D}_{3}$, and calcitonin. A low calcium increases PTH secretion and $1,25(\mathrm{OH})_{2} \mathrm{D}_{3}$ synthesis and decreases calcitonin secretion, while a high

calcium has the opposite effect. PTH and calcitonin both stimulate $1,25(\mathrm{OH})_{2} \mathrm{D}_{3}$ synthesis while $1,25(\mathrm{OH})_{2} \mathrm{D}_{3}$ decreases the synthesis of PTH and calcitonin.

$1,25(\mathrm{OH})_{2} \mathrm{D}_{3}$ regulates calcitonin gene transcription therefore establish an endocrinological loop as well as a new role for $1,25(\mathrm{OH})_{2} \mathrm{D}_{3}$.

Jacobs et al. (25) studied the effect of high calcium (up to 5 $\mathrm{mM}$ ) on the in vitro production of calcitonin mRNA in rat thyroid slices. Up to $6 \mathrm{~h}$ there was no increase in calcitonin mRNA from calcium-stimulated thyroid slices, despite a linear increase in calcitonin secretion in response to calcium from similar thyroid preparations (26). Therefore, calcium is the primary regulator of calcitonin secretion, but has not been shown to regulate calcitonin synthesis. In the present studies small physiologically relevant doses of $1,25(\mathrm{OH})_{2} \mathrm{D}_{3}$ (e.g., 12.5 $\mathrm{pmol} / 150 \mathrm{~g}$ rat) were injected that had no effect on serum calcium, but reduced calcitonin mRNA by $>90 \%$ at $48 \mathrm{~h}$, with a similar effect on PTH mRNA. In order to determine the importance of this effect in physiology further investigations are planned where small doses of $1,25(\mathrm{OH})_{2} \mathrm{D}_{3}$ will be injected into rats that would not affect the serum calcium, and circulating levels of PTH and calcitonin assayed. The results reported here together with our previous studies of the effect of $1,25(\mathrm{OH})_{2} \mathrm{D}_{3}$ on PTH gene regulation (1) indicate that while calcium concentration regulates $\mathrm{PTH}$ and calcitonin hormone secretion, $1,25(\mathrm{OH})_{2} \mathrm{D}_{3}$ is an important regulator of PTH and calcitonin gene transcription (Fig. 5).

\section{Acknowledgments}

We thank Dr. Howard Cedar for helpful discussions, Ms. Mirian Ofner for technical assistance, Dr. M. J. Rosenfeld for the rat calcitonin gene, Dr. Vassart for the rat thyroglobulin gene, and Dr. F. Baldino for the somatostatin polynucleotide.

This work was supported by grants from the Fund for Basic Research of the Israel Academy of Sciences, and by grant 86-71 from the United States-Israel Binational Science Foundation (BSF), Jerusalem, Israel. Dr. Naveh-Many is a fellow of the Israel Cancer Research Fund.

\section{References}

1. Silver, J., T. Naveh-Many, H. Mayer, H. J. Schmelzer, and M. M. Popovtzer. 1986. Regulation by vitamin D metabolites of parathyroid hormone gene transcription in vivo in the rat. J. Clin. Invest. 78:1296-1301.

2. Silver, J., J. Russell, and L. M. Sherwood. 1985. Regulation by vitamin $\mathrm{D}$ metabolites of messenger ribonucleic acid for preproparathyroid hormone in isolated bovine parathyroid cells. Proc. Natl. Acad. Sci. USA. 82:4270-4273.

3. Galante, L., K. W. Colston, S. J. MacAuley, and I. Macintyre. 1972. Effect of calcitonin on vitamin D metabolism. Nature (Lond.). 238:271-273. 
4. Horiuchi, N., H. Takahashi, T. Matsumoto, N. Takahashi, E. Shimazawa, T. Suda, and E. Ogata. 1979. Salmon calcitonin-induced stimulation of 1,25-dihydroxycholecalciferol synthesis in rats involving a mechanism independent of adenosine $3^{\prime}: 5^{\prime}$-cyclic mono-phosphate. Biochem. J. 184:269-275.

5. Jaeger, P., W. Jones, T. L. Clemens, and J. P. Hayslett. 1982. Evidence that calcitonin stimulates 1,25 -dihydroxyvitamin $\mathrm{D}$ production and intestinal absorption of calcium in vivo. J. Clin. Invest. 78:456-461.

6. Kawashima, H., S. Torikai, and R. Kurokawa. 1981. Calcitonin selectively stimulates 25 -hydroxyvitamin $\mathrm{D}_{3}-1$-hydroxylase in the proximal straight tubules of rat kidney. Nature (Lond). 298:327-329.

7. Desplan, C., C. Benicorert, A. Julliene, N. Segond, C. Calmettes, M. S. Moukhtar, and G. Milhaud. 1980. Cell free transplation of mRNA coding for human and murine calcitonin. FEBS (Fed. Eur. Biochem. Soc.) Lett. 117:89-92.

8. Wolfe, H. J., and R. A. Delellis. 1981. Familial medullary thyroid carcinoma and $\mathrm{C}$ cell hyperplasia. In Clinics in Endocrinology and Metabolism. E. D. Williams, editor. Vol. 10. W. B. Saunders, London. 351-361.

9. Freake, H. C., and I. MacIntyre. 1982. Specific binding of 1,25dihydroxycholecalciferol in human medullary thyroid carcinoma. Biochem. J. 206;181-184.

10. Heynen, G., F. Cornet, P. Franchimont, S. Gasper, G. Plomteux, G. Cession-Fossion, R. G. G. Russel, and J. A. Kanis. 1981 Comparison of acute effects of 1,25- and 24,25-dihydroxyvitamin $D_{3}$ in normal subjects. Acta Endocrinol. 981:619-624.

11. Raue, F., I. Deutschle, and R. Ziegler. 1983. Acute effects of 1,25-dihydroxyvitamin $\mathrm{D}_{3}$ on calcitonin secretion in rats. Horm. Metab. Res. 15:208-209.

12. Raue, F., I. Deutschle, C. Kuntzel, and R. Ziegler. 1984. Reversible diminished calcitonin secretion in the rat during chronic hypercalcemia. Endocrinology. 115:2362-2367.

13. Segond, N., B. Legendre, E. H. Tahri, P. Besnard, A. Jullienne, M. S. Moukhtar, and J.-M. Garel. 1985. Increased level of calcitonin mRNA after 1,25-dihydroxyvitamin $D_{3}$ injection in the rats. FEBS (Fed. Eur. Biochem. Soc.) Lett. 184:268-272.

14. Parsons, J. A., S. L. Erlandsen, O. D. Hergre, R. C. McEvoy, R. C. McEvoy, and R. P. Elde. 1976. Central and peripheral localization of somatostatin immunoenzyme immunocytochemical studies. $J$. Histochem. Cytochem. 24:872-882.

15. Chirgwin, J. M., A. R. Przybla, R. J. MacDonald, and W. J.
Rutter. 1979. Isolation of biologically active ribonucleic acid from sources enriched in ribonuclease. Biochemistry. 18:5294-5299.

16. Amara, S. G., D. N. David, M. G. Rosenfeld, B. A. Roos, and R. M. Evans. 1980. Characterization of rat calcitonin mRNA. Proc Natl. Acad. Sci. USA. 77:4444-4448.

17. Brocas, H., D. Christophe, B. Van Heuverswijn, N. Scherberg, and G. Vassart. 1980. Molecular cloning of Pst I fragments from rat double stranded thyroglobulin complementary DNA. Biochem. Biophys. Res. Commun. 96:1785-1792.

18. Arentzen, R., F. Baldino, Jr., L. G. Davis, G. A. Higgins, Y. Lin,. R. W. Manning, and B. Wolfson. 1985. In situ hybridization of putative somatostatin mRNA within hypothalamus of the rat using synthetic oligonucleotide probes. J. Cell Biochem. 27:415-422.

19. Spencer, R., M. Charman, and D. E. M. Lawson. 1978. Stimulation of intestinal calcium-binding protein mRNA synthesis in the nucleus of vitamin D-deficient chicks by 1,25-dihydroxycholecalciferol. Biochem. J. 175:1089-1094.

20. Price, P. A., and S. A. Baukol. 1981. 1,25-dihydroxyvitamin $D_{3}$ increases serum levels of the vitamin K-dependent bone protein. Biochem. Biophys. Res. Commun. 99:928-935.

21. Wark, J. D., and A. H. Tashjian, Jr. 1983. Regulation of prolactin mRNA by 1,25 -dihydroxyvitamin $\mathrm{D}_{3}$ in $\mathrm{GH}_{4} \mathrm{C}_{1}$ cells. $J$. Biol. Chem. 258:12118-12121.

22. Charles, M. D., J. Martial, D. Zolock, R. Morrissey, and J. D. Baxter. 1981. Regulation of calcium-binding protein messenger RNA by 1,25-dihydroxycholecalciferol. Calcif. Tissue Int. 33:15-18.

23. Reitsma, P. H., P. G. Rothberg, S. M. Astrin, J. Trial, Z. Bar-Shavit, A. Hall, S. L. Teitelbaum, and A. J. Kahn. 1983. Regulation of myc gene expression in HL-60 leukaemia cells by a vitamin D metabolite. Nature (Lond.). 306:492-494.

24. Rosenfeld, M. G., S. G. Amara, N. C. Bimberg, J.-J. Mermod, G. H. Murdoch, and R. M. Evans. 1983. Calcitonin, prolactin and growth hormone gene expression as model systems for the characterization of neuroendocrine regulation. Recent Prog. Horm. Res. 39:305-351.

25. Jacobs, J. W., E. Simpson, J. Penschow, P. Hudson, J. Coghlan, and $H$. Niall. 1983. Characterization and localization of calcitonin messenger ribonucleic acid in rat thyroid. Endocrinology. 113:16161622.

26. Bell, N. H., and S. Queener. 1974. Stimulation of calcitonin synthesis and release in vitro by calcium and dibutyryl cyclic AMP. Nature (Lond.). 248:343-344. 